\title{
Humanoid Dancer Robot Movement Synchronization System with Zigbee
}

\section{Sistem Sinkronisasi Gerakan Robot Penari Humanoid dengan Zigbee}

\author{
Ponco Sukaswanto ${ }^{1}$, Abdul Fadlil ${ }^{2}$ \\ ${ }^{1}$ Mahasiswa Program Studi Teknik Elektro, Universitas Ahmad Dahlan, Indonesia \\ ${ }^{2}$ Dosen Program Studi Teknik Elektro, Universitas Ahmad Dahlan, Indonesia
}

\section{INFORMASI ARTIKEL}

\section{Riwayat Artikel:}

Dikirimkan 23 Agustus 2020,

Direvisi 10 September 2020,

Diterima 13 September 2020.

\section{Kata Kunci:}

Robot,

KRSTI,

Audio Analyzer,

Zigbee,

XBee S2C.

\section{Penulis Korespondensi:}

Nama, Ponco Sukaswanto Institusi/Afiliasi, Universitas Ahmad Dahlan

Alamat, Negara. Indonesia Surel/Email:

sukaswantop@gmail.com

\begin{abstract}
ABSTRAK
This research proposes a wireless communication between two dancer robots using zigbee to overcome the differences in movement between the robots in order to dance in harmony. The robotic music processor uses Audio Analyzer $V 2.0$ which functions to get 7 frequency values for the music being played. The frequency will be processed by Arduino to determine the condition of the music on and off which will be sent to each robot via the XBee S2C module using the Zigbee method, namely with 1 master and 2 routers. The result is that the music processing system becomes more robust because it uses the Zigbee method. By using the Zigbee method, robot 1 and robot 2 can also communicate with each other because with this method, fellow routers can exchange data. The robot produced by this study can already distinguish the conditions when music is playing or muted, and between robot 1 and robot 2 can communicate with each other. Communication between robots functions so that when one of the robots is late in getting data, the other robots will wait until the late robot completes its movements so that robot 1 and robot 2 are back in sync.
\end{abstract}

Pada penelitian ini mengusulkan tentang komunikasi nirkabel antara dua robot penari dengan menggunakan zigbee untuk mengatasi perbedaan gerakan antara robot agar dapat menari dengan selaras. Pengolah musik robot menggunakan Audio Analyzer V2.0 yang berfungsi untuk mendapatkan 7 nilai frekuensi pada musik yang sedang diputar. Frekuensi tersebut akan diolah oleh Arduino untuk menentukan kondisi musik hidup dan mati yang akan dikirim ke masing-masing robot melalui modul XBee S2C menggunakan metode Zigbee yaitu dengan 1 master dan 2 router. Hasil yang didapat adalah sistem pengolah musik menjadi lebih tangguh karena menggunakan metode Zigbee. Dengan menggunakan metode Zigbee maka antar robot 1 dan robot 2 juga dapat saling melakukan komunikasi karena dengan metode ini sesama router dapat saling bertukar data. Robot yang dihasilkan oleh penelitian ini sudah dapat membedakan kondisi ketika musik sedang diputar atau dibisukan, dan antara robot 1 dan robot 2 sudah dapat saling berkomunikasi. Komunikasi antar robot berfungsi supaya ketika salah satu robot ada yang terlambat mendapatkan data maka robot yang lainnya akan menunggu sampai robot yang terlambat menyelesaikan gerakannya sehingga robot 1 dan robot 2 kembali selaras.

This work is licensed under a Creative Commons Attribution-Share Alike 4.0

\section{Sitasi Dokumen ini:}

P. Sukaswanto and A. Fadlil, "Dance Movement Synchronization System between Humanoid Robots and Zigbee," Buletin Ilmiah Sarjana Teknik Elektro, vol. 2, no. 3, pp. 103-110, 2020. DOI: 10.12928/biste.v2i3.2695 


\section{PENDAHULUAN}

KRSTI (Kontes Robot Seni Tari Indonesia) adalah salah satu ajang kompetisi yang ada di Kontes Robot Indonesia (KRI) yang berfokus pada perancangan, pembuatan dan pemrograman robot yang disertai unsurunsur seni budaya Indonesia khususnya seni tari yang terkenal di bumi pertiwi, KRSTI diselenggarakan setiap tahun sejak tahun 2010 hingga sekarang [1].

Zigbee adalah salah satu jenis jaringan komunikasi nirkabel dengan karakteristik komunikasi jarak pendek, biaya murah dan konsumsi daya yang rendah. Teknologi zigbee telah digunakan di banyak kehidupan sehari-hari salah satunya adalah keperluan komunikasi dalam dunia robotika [2][3].

Dalam mengolah nilai frekuensi musik dilakukan menggunakan modul audio analyzer V2.0 yang mana cara kerja dari modul ini adalah dengan cara membagi spectrum audio menjadi tujuh frekuensi dengan rentan nilai $63 \mathrm{~Hz}, 16 \mathrm{~Hz}, 400 \mathrm{~Hz}, 1 \mathrm{kHz}, 2,5 \mathrm{kHz}, 6,25 \mathrm{kHz}$, dan 16kHz. Modul audio analyzer V2.0 ini dikendalikan oleh dua pin yaitu Strobe dan Reset. Kecepatan dalam pembacaan multiplekser ini juga mengendalikan decay rate (susutan) sebesar 10\% setiap pembacaan [4].

Penelitian ini dilakukan untuk mengatasi masalah yang timbul khususnya dalam keselarasan antar robot satu dengan yang lain ketika melakukan gerakan tari dan memperbaiki sistem pemancar musik yang sudah ada, karena pada tahun sebelumnya kedua robot tim KRSTI UAD belum dapat saling berkomunikasi dan itu menyebabkan gerakan tari antar robot tidak sinkron ketika sistem pemancar mendapatkan gangguan seperti tembok di hadapannya atau jarak antara sistem pemancar dan robot lebih dari 5 meter. Hal ini sangatlah berpengaruh terhadap hasil akhir kontes robot seni tari karena keselarasan antar robot memiliki poin yang cukup tinggi yaitu 10 poin dan ketika gerakan antara robot tidak selaras maka poin keselarasan akan hilang.

Penelitian ini merujuk dari penelitian yang telah dilakukan oleh para peneliti sebelumnya. Penelitian yang dilakukan oleh Aryanti dkk dengan judul "Implementasi Sensor Suara Sebagai Pengendali Gerakan Robot" penelitian ini bertujuan untuk mengetahui prinsip kerja sensor suara sebagai kontrol gerak robot penari humanoid dengan mikrokontroler ATMEGA 8535 [5]. Penelitian selanjutnya adalah yang dilakukan oleh zade dkk dengan judul "X-bee Based Spy Robot with Night Vision Camera" Penelitian ini memberikan ulasan tentang teknologi Zigbee, karakteristiknya, aliansinya, metode aksesnya, perangkat dan topologi yang didukung oleh Zigbee. Bagian terpenting dari penelitian ini adalah arsitektur protokol Zigbee dan aplikasinya dalam Spy Robot dengan kamera night vision [6].

Pada penelitian yang akan dilakukan adalah membuat sistem pengolah musik menggunakan audio analyzer V2.0 dan XBee S2C. Hasil yang didapat dari audio analyzer V2.0 akan diolah pada Arduino dengan cara membaca 7 nilai frekuensi yang dibaca oleh audio analyzer V2.0 kemudian 7 frekuensi tersebut akan dijumlahkan untuk menentukan ada atau tidaknya musik. Setelah itu hasil yang didapat akan dikirim ke robot 1 dan robot 2 secara bersamaan menggunakan XBee S2C dengan menggunakan metode Zigbee yaitu 1 master yang terdapat pada sistem pengolah musik dan 2 router yang terdapat pada robot 1 dan robot 2 . XBee yang terdapat pada masing-masing robot juga berfungsi sebagai alat komunikasi antar robot.

\section{METODE PENELITIAN}

Pada penelitian yang akan dilakukan adalah untuk membuat sistem pengolah musik menggunakan audio analyzer V2.0 kemudian hasil yang didapat akan diolah pada Arduino dengan cara membaca 7 nilai frekuensi yang dapat dibaca oleh audio analyzer V2.0 kemudian 7 frekuensi tersebut akan dijumlahkan untuk menentukan ada atau tidaknya musik [7]. Setelah itu hasil yang didapat akan dikirim ke robot 1 dan robot 2 secara bersamaan menggunakan XBee S2C dengan menggunakan metode zigbee yaitu 1 master yang terdapat pada sistem pengolah musik dan 2 router yang terdapat pada robot 1 dan robot 2 [8]. XBee yang terdapat pada masing-masing robot juga berfungsi sebagai alat komunikasi antar robot.

\subsection{Sistem Pengolah Musik}

Perancangan sistem pengolah musik pada penelitian ini dengan cara melakukan sampling fekuensi untuk menentukan ada atau tidak musik kemudian hasil sampling dikirim ke perangkat keras melalui modul XBee S2C. Gambar 1 merupakan diagram blok pada perangkat keras sistem pengolah musik yang dihubungkan dengan jack audio yang telah disediakan. Ketika musik diputar maka perangkat akan menerima sinyal frekuensi musik dan akan diolah dalam mikrokontroller Arduino pro mikro, setelah diproses maka Arduino pro mikro akan mengeluarkan isyarat gerak robot yang akan menentukan apakah robot harus berhenti atau bergerak [9]. Isyarat gerak juga akan ditampilkan pada LCD OLED untuk mempermudah dalam pengamatan dan isyarat gerak juga akan dikiriman ke robot 1 dan robot 2 melalui Xbee.

Gambar 2 merupakan diagram alir perangkat keras sistem pengolah musik. Ketika sistem dinyalakan maka sistem akan menampilkan opsi yaitu musik dan setting, pada setting adalah untuk menentukan level pada sistem pengolahan musik sedangkan untuk musik sistem akan membaca spectrum audio yang diterima melalui jack audio, kemudian spectrum tersebut dipecah menjadi tujuh frekuensi yang berbeda yang akan diolah pada 
microcontroller untuk diubah menjadi isyarat gerak ataupun isyarat berhenti dengan acuan nilai frekuensi yang didapat. Isyarat gerak atau isyarat berhenti tersebut kemudian dikirimkan ke robot melalui XBee.

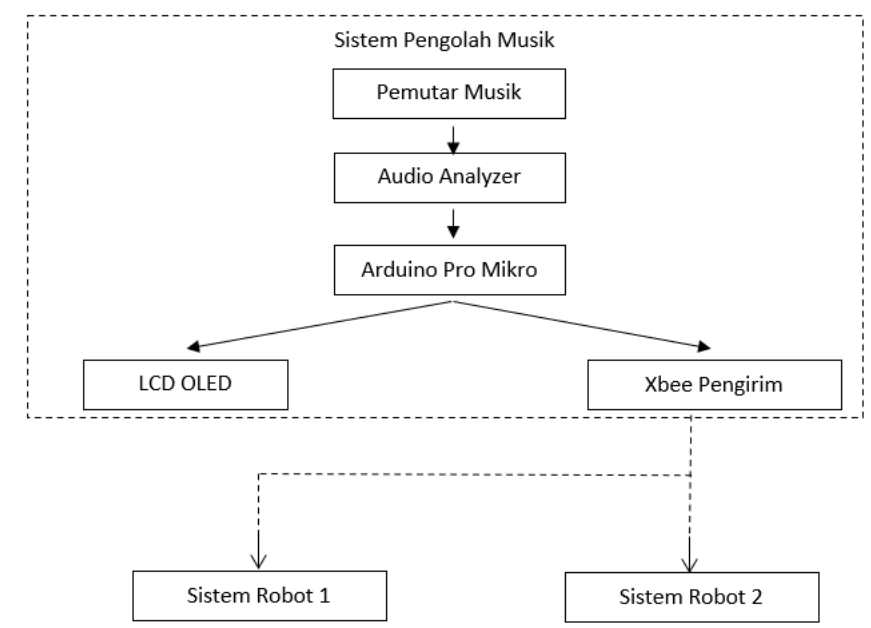

Gambar 1. Diagram Blok Sistem Pengolah Musik

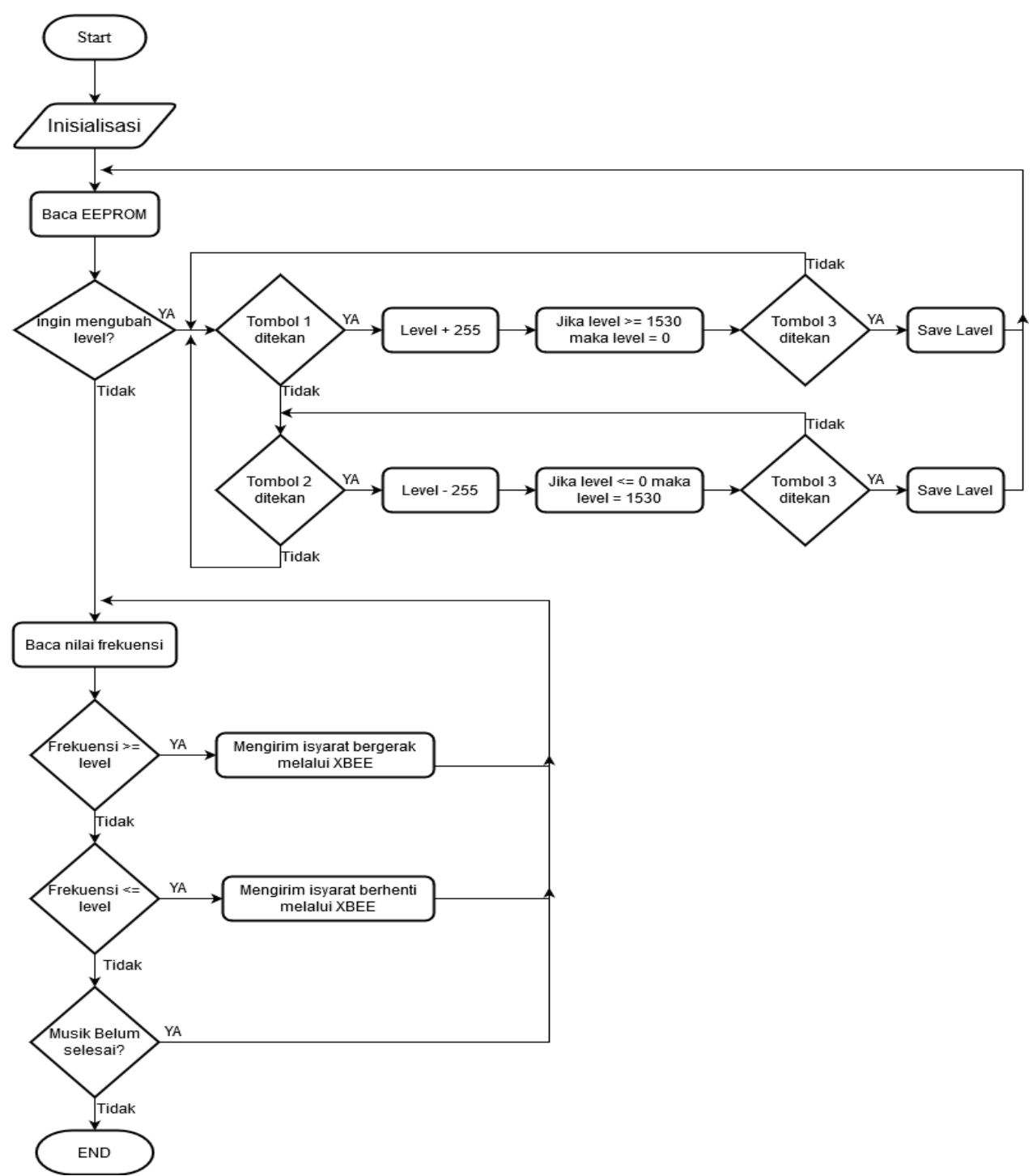

Gambar 2. Diagram Alir Sistem Pengolah Musik 


\subsection{Sistem Robot}

Dalam pembuatan robot bahan yang digunakan adalah plat aluminium dengan ketebalan $2 \mathrm{~mm}$ untuk bagian badan dan kaki. Sedangkan bahan 3D printing untuk bagian tangan kemudian untuk bagian telapak kaki menggunakan bahan akrilik dengan ketebalan $3 \mathrm{~mm}$ dan untuk bagian kepala menggunakan kepala boneka yang ukurannya sesuai, desain 3D robot humanoid dapat dilihat pada gambar 3 [10].

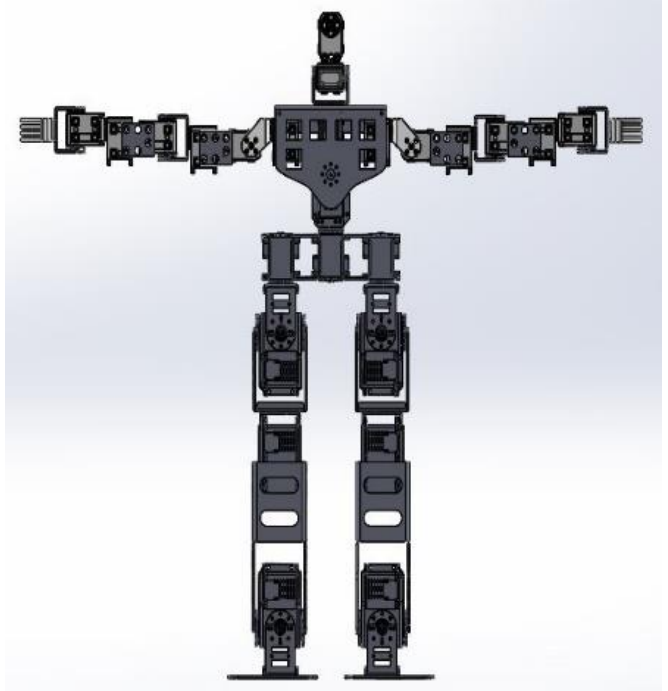

Gambar 3. Desain 3D Robot Humanoid

Blok diagram sistem robot satu dan robot dua dapat diamati melalui Gambar 4, Apabila sistem robot 1 dan robot 2 mendapat isyarat gerak dari sistem pengolah musik, isyarat akan diproses dalam kontroller Arduino mega pro begitu juga isyarat perpindahan gerak yang dikirim dari robot satu ke robot lainnya. Ketika terdapat instruksi untuk robot bergerak maka Arduino mega pro akan mengirimkan nilai-nilai servo ke OpenCM 9.04 yang kemudian diteruskan ke papan ekspansi OpenCM 485. Setelah melalui papan ekspansi OpenCM 485 maka nilai-nilai servo akan diterima oleh masing-masing aktuator robot untuk mendapatkan gerakan yang sesuai. Gerakan tari dibuat dengan cara merekam nilai-nilai servo pada posisi yang diinginkan, susunan nilainilai servo tersebutlah yang nantinya akan digabungkan menjadi tari jaipong.

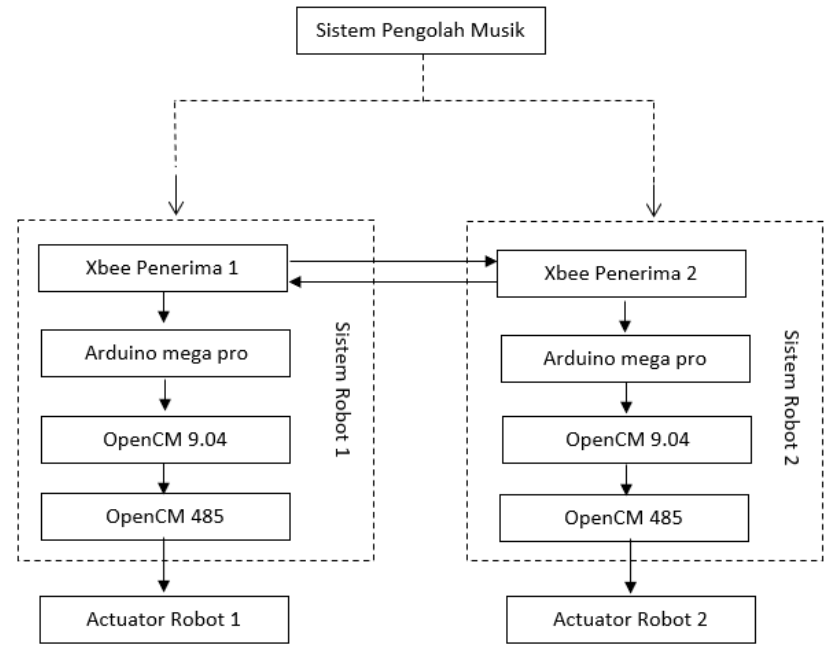

Gambar 4. Diagram Blok Sistem Robot Satu dan Robot Dua

Diagram alir robot dapat dilihat pada Gambar 4, Arduino mega pro akan menunggu isyarat dari sistem pengolah musik dan robot lainnya melalui XBee. Ketika mendapat isyarat gerak maka akan diproses oleh Arduino mega pro apakah isyarat tersebut bergerak atau berhenti, jika isyarat tersebut untuk bergerak maka sistem akan menjalankan gerakan dengan memanggil gerakan yang telah dibuat secara berurutan dari satu hingga seterusnya. Ketika robot sedang menari dan robot mendapat isyarat untuk berhenti maka gerakan akan dihentikan dengan menghentikan hitungan gerakan dalam sistem [11]. 


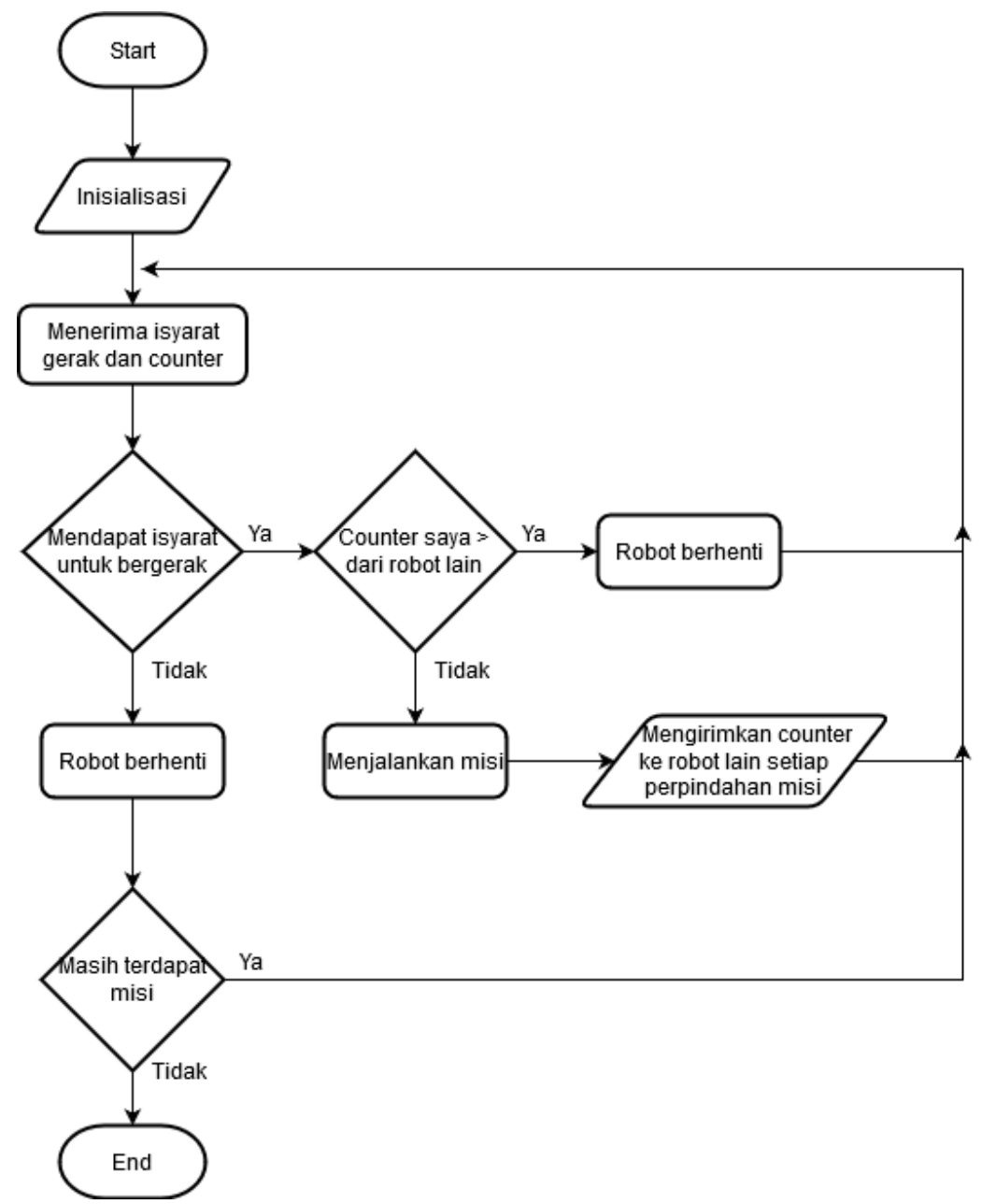

Gambar 5. Diagram Alir Sistem Robot

\section{HASIL PEMBAHASAN}

\subsection{Pengiriman Isyarat Sistem Pengolah Musik}

Pengiriman isyarat gerak robot dilakukan dengan menggunakan XBee S2C sebanyak 3 buah, satu digunakan sebagai master yang terpasang pada pengolah musik dan dua sisanya sebagai router yang terpasang pada robot 1 dan robot 2. Pengaturan XBee S2C sebagai master dan router dapat dilihat pada Tabel 1.

Tabel 1 Pengaturan XBee S2C Antara Master, Router 1 dan Router 2

\begin{tabular}{|l|c|c|c|}
\hline \multicolumn{1}{|c|}{ Perintah } & Master & Router 1 & Router 2 \\
\hline ID PAN & 9999 & 9999 & 9999 \\
\hline JV Chanel Verification & Disabled [0] & Enabled [1] & Enabled [1] \\
\hline CE Coordinator Enable & Enabled [1] & Disabled [0] & Disabled [0] \\
\hline $\begin{array}{l}\text { DH Destination Address } \\
\text { High }\end{array}$ & 0 & $13 \mathrm{~A} 200$ & $13 \mathrm{~A} 200$ \\
\hline $\begin{array}{l}\text { DL Destination Address } \\
\text { Low }\end{array}$ & FFFF & 41855325 & $4185473 \mathrm{~F}$ \\
\hline NI Node Identifier & LJ-CORDINATOR & LJ-ROUTER1 & LJ-ROUTER2 \\
\hline PL Power Level & Highest [4] & Highest [4] & Highest [4] \\
\hline BD Boud Rate & $9600[3]$ & $9600[3]$ & 9600 [3] \\
\hline AP API Enable & Transparent Mode [0] & Transparent Mode [0] & Transparent Mode [0] \\
\hline
\end{tabular}

Sistem pengolah musik akan mengirimkan isyarat gerak berupa bilangan biner, yang mana sistem akan mengirimkan nilai 1 apabila sistem mendeteksi adanya musik dan sistem akan mengirimkan nilai 0 apabila sistem tidak mendeteksi musik. Hasil pengiriman isyarat gerak oleh sistem pengolah musik dapat diihat pada Gambar 6 untuk musik on dan Gambar 7 untuk music off. 


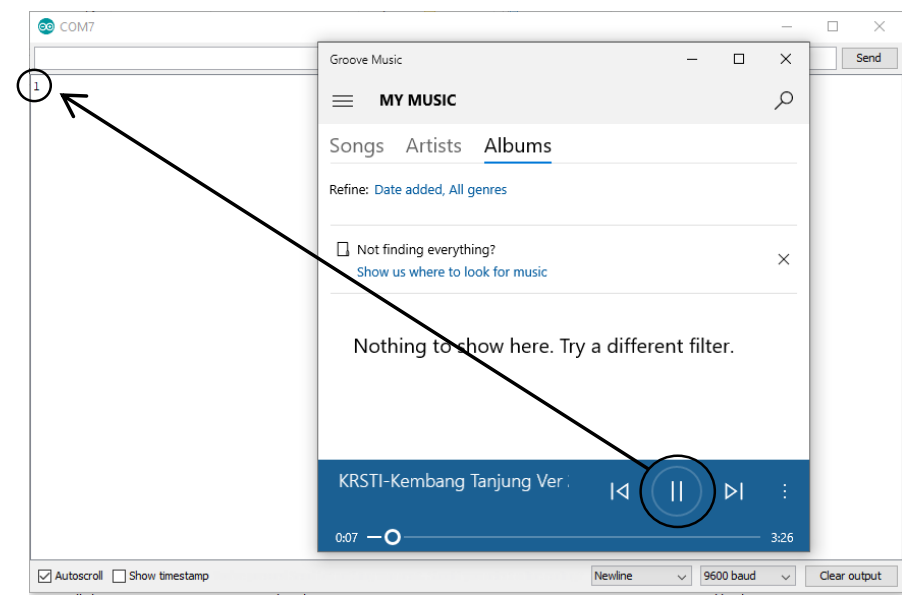

Gambar 6. Hasil Pengiriman Isyarat Gerak Ketika Musik On

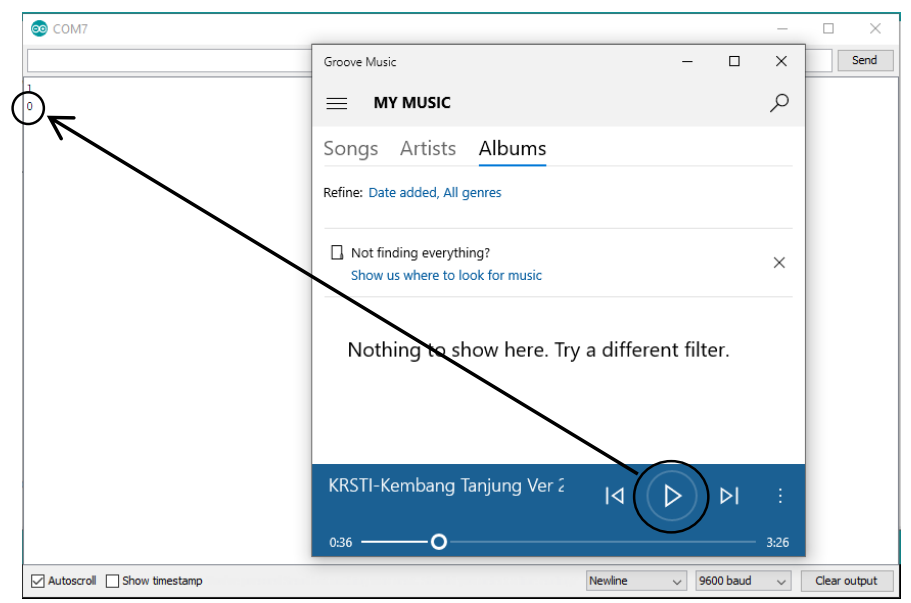

Gambar 7. Hasil Pengiriman Isyarat Gerak Ketika Musik off

\subsection{Sistem Robot $1 \&$ Robot 2}

Pada sistem robto 1 dan robot 2 memiliki 2 buah mikrokontroller yaitu Arduino Mega PRO dan OpenCM 9.04. Arduino Mega PRO berfungsi untuk menyimpan data gerakan dan untuk memproses komunikasi antara robot dan sistem pengolah musik juga antara robot 1 dan robot 2. Sedangkan OpenCM 9.04 berfungsi sebagai jembatan antara Arduino Mega PRO dengan servo dynamixel. Ketika robot 1 \& robot 2 mendapatkan isyarat gerak dari sistem pengolah musik, maka kedua robot akan bergerak secara bersamaan dan ketika salah satu dari robot terlambat menerima data dari sistem pengolah musik maka robot yang terlebih dahulu mendapatkan data akan menunggu robot yang terlambat mendapatkan data.

Pengujian sistem pengolah musik dilakukan dengan 2 kondisi yaitu kondisi ketika diantara sistem pengolah musik dan robot tidak ada penghalang, dan kondisi ketika diantara sistem pengolah musik dan robot dihalangi oleh tembok. Sistem pemgolah musik akan mendeteksi musik dari pemutar musik melalui jack audio lalu sistem pengolah musik akan memgirimkan isyarat berupa bilangan biner yaitu nilai 1 ketika sistem mendeteksi musik dan nilai 0 ketika sistem tidak mendeteksi adanya musik. Hasil waktu pengiriman antara sistem pengolah musik dan robot dapat dilihat pada Tabel 2.

Tabel 2 Hasil Uji Coba Pengiriman Data Dari Sistem Pengolah Musik ke Robot

\begin{tabular}{|c|c|c|c|c|}
\hline \multirow{2}{*}{ Uji Ke- } & \multicolumn{3}{|c|}{ Waktu pengiriman data (detik) } \\
\cline { 2 - 5 } & $\begin{array}{c}\text { Pengiriman kondisi } \\
\text { hidup tanpa ada halangan }\end{array}$ & $\begin{array}{c}\text { Pengiriman kondisi } \\
\text { mati tanpa ada } \\
\text { halangan }\end{array}$ & $\begin{array}{c}\text { Pengiriman kondisi } \\
\text { hidup dihalangi tembok }\end{array}$ & $\begin{array}{c}\text { Pengiriman kondisi mati } \\
\text { dihalangi tembok }\end{array}$ \\
\hline 1 & 0,22 & 1,05 & 0,60 & 1,18 \\
\hline 2 & 0,38 & 0,78 & 0,56 & 1,18 \\
\hline 3 & 0,25 & 0,75 & 0,53 & 1,52 \\
\hline
\end{tabular}




\begin{tabular}{|c|c|c|c|c|}
\hline \multirow{2}{*}{ Uji Ke- } & \multicolumn{4}{|c|}{ Waktu pengiriman data (detik) } \\
\cline { 2 - 5 } & $\begin{array}{c}\text { Pengiriman kondisi } \\
\text { hidup tanpa ada halangan }\end{array}$ & $\begin{array}{c}\text { Pengiriman kondisi } \\
\text { mati tanpa ada } \\
\text { halangan }\end{array}$ & $\begin{array}{c}\text { Pengiriman kondisi } \\
\text { hidup dihalangi tembok }\end{array}$ & $\begin{array}{c}\text { Pengiriman kondisi mati } \\
\text { dihalangi tembok }\end{array}$ \\
\hline 4 & 0,35 & 0,90 & 0,61 & 1,56 \\
\hline 5 & 0,32 & 0,97 & 0,69 & 1,62 \\
\hline 6 & 0,37 & 1,09 & 0,62 & 1,55 \\
\hline 7 & 0,37 & 1,04 & 0,52 & 1,59 \\
\hline 8 & 0,35 & 1,10 & 0,47 & 1,65 \\
\hline 9 & 0,42 & 0,97 & 0,53 & 1,48 \\
\hline 10 & 0,34 & 0,90 & 0,72 & 1,46 \\
\hline Rata-rata & 0,337 & 0,955 & 0,585 & 1,478 \\
\hline
\end{tabular}

Komunikasi antara robot 1 dan robot 2 dilakukan dengan cara mengirimkan nilai 1-13 yang mana nilai tersebut mewakili dari setiap gerakan yang ada pada robot. Setiap perpindahan gerakan robot akan selalu berkomunikasi dengan robot lainnya untuk memastikan tidak ada robot yang terlambat dalam melakukan gerakan. Komunikasi dikatakan berhasil apabila robot 1 dan robot 2 dapat mengirim dan menerima data satu sama lain tidak lebih dari 500ms. Hasil uji komunikasi antara robot 1 dan robot 2 dapat dilihat pada tabel 3.

Tabel 3 Hasil Uji Coba Komunikasi Antar Robot 1 dan Robot 2

\begin{tabular}{|c|c|c|c|c|c|c|c|c|c|c|c|}
\hline \multirow{2}{*}{$\mathrm{NO}$} & \multirow{2}{*}{ Musik Pada Gerakan } & \multicolumn{10}{|c|}{ Percobaan } \\
\hline & & 1 & 2 & 3 & 4 & 5 & 6 & 7 & 8 & 9 & 10 \\
\hline 1 & Sembah Pembuka 1 & $\mathrm{~T}$ & $\mathrm{~T}$ & $\mathrm{~T}$ & $\mathrm{~T}$ & $\mathrm{~T}$ & $\mathrm{~T}$ & $\mathrm{~T}$ & $\mathrm{~T}$ & $\mathrm{~T}$ & $\mathrm{~T}$ \\
\hline 2 & Sembah Pembuka 2 & $\mathrm{~T}$ & $\mathrm{~T}$ & $\mathrm{~T}$ & $\mathrm{~T}$ & $\mathrm{~T}$ & $\mathrm{~T}$ & $\mathrm{~T}$ & $\mathrm{~T}$ & $\mathrm{~T}$ & $\mathrm{~T}$ \\
\hline 3 & Pancungan 1 & $\mathrm{~T}$ & $\mathrm{~T}$ & $\mathrm{~T}$ & $\mathrm{~T}$ & $\mathrm{~T}$ & $\mathrm{~T}$ & $\mathrm{~T}$ & $\mathrm{~T}$ & $\mathrm{~T}$ & $\mathrm{~T}$ \\
\hline 4 & Pancungan 2 & $\mathrm{~T}$ & $\mathrm{~T}$ & $\mathrm{~T}$ & $\mathrm{~T}$ & $\mathrm{~T}$ & $\mathrm{~T}$ & $\mathrm{~T}$ & $\mathrm{~T}$ & $\mathrm{~T}$ & $\mathrm{~T}$ \\
\hline 5 & Jalan & $\mathrm{T}$ & $\mathrm{T}$ & $\mathrm{T}$ & $\mathrm{T}$ & $\mathrm{T}$ & $\mathrm{T}$ & $\mathrm{T}$ & $\mathrm{T}$ & $\mathrm{T}$ & $\mathrm{T}$ \\
\hline 6 & Ngala & $\mathrm{T}$ & $\mathrm{T}$ & $\mathrm{T}$ & $\mathrm{T}$ & $\mathrm{T}$ & $\mathrm{T}$ & $\mathrm{T}$ & $\mathrm{T}$ & $\mathrm{T}$ & $\mathrm{T}$ \\
\hline 7 & Mincit Kendor & $\mathrm{T}$ & $\mathrm{T}$ & $\mathrm{T}$ & $\mathrm{T}$ & $\mathrm{T}$ & $\mathrm{T}$ & $\mathrm{T}$ & $\mathrm{T}$ & $\mathrm{T}$ & $\mathrm{T}$ \\
\hline 8 & Jalan & $\mathrm{T}$ & $\mathrm{T}$ & $\mathrm{T}$ & $\mathrm{T}$ & $\mathrm{T}$ & $\mathrm{T}$ & $\mathrm{T}$ & $\mathrm{T}$ & $\mathrm{T}$ & $\mathrm{T}$ \\
\hline 9 & Mincit Gancang & $\mathrm{T}$ & $\mathrm{T}$ & $\mathrm{T}$ & $\mathrm{T}$ & $\mathrm{T}$ & $\mathrm{T}$ & $\mathrm{T}$ & $\mathrm{T}$ & $\mathrm{T}$ & $\mathrm{T}$ \\
\hline 10 & Jalan & $\mathrm{T}$ & $\mathrm{T}$ & $\mathrm{T}$ & $\mathrm{T}$ & $\mathrm{T}$ & $\mathrm{T}$ & $\mathrm{T}$ & $\mathrm{T}$ & $\mathrm{T}$ & $\mathrm{T}$ \\
\hline 11 & Nabakeun & $\mathrm{T}$ & $\mathrm{T}$ & $\mathrm{T}$ & $\mathrm{T}$ & $\mathrm{T}$ & $\mathrm{T}$ & $\mathrm{T}$ & $\mathrm{T}$ & $\mathrm{T}$ & $\mathrm{T}$ \\
\hline 12 & Jalan & $\mathrm{T}$ & $\mathrm{T}$ & $\mathrm{T}$ & $\mathrm{T}$ & $\mathrm{T}$ & $\mathrm{T}$ & $\mathrm{T}$ & $\mathrm{T}$ & $\mathrm{T}$ & $\mathrm{T}$ \\
\hline 13 & Sembah Penutup & $\mathrm{T}$ & $\mathrm{T}$ & $\mathrm{T}$ & $\mathrm{T}$ & $\mathrm{T}$ & $\mathrm{T}$ & $\mathrm{T}$ & $\mathrm{T}$ & $\mathrm{T}$ & $\mathrm{T}$ \\
\hline
\end{tabular}

*(X) komunikasi robot terlambat, (T) komunikasi robot tepat

Pada uji coba komunikasi antar robot dapat dihitung tingkat keberhasilan komunikasi yang dilakukan antar robot dengan menghitung persamaan sebagai berikut.

$$
\begin{gathered}
\text { Tingkat Keberhasilan }=\frac{\text { Banyak Percobaan yang Berhasil }}{\text { Jumlah Percobaan yang Dilakukan }} \times 100 \% \\
\text { Tingkat Keberhasilan }=\frac{10}{10} \times 100 \%=100 \%
\end{gathered}
$$

Setelah melakukan percobaan maka didapat hasil tingkat keberhasilan robot melakukan komunikasi satu dengan yang lain adalah $100 \%$. Dengan rata-rata respon time robot menerima data dari sistem pengolah musik ketika diantara sistem pengolah musik dan robot tidak ada yang menghalangi adalah 0,337 detik untuk penerimaan kondisi musik hidup dan 0,955 untuk kondisi musik mati. Sedangkan untuk rata-rata respon time robot menerima data dari sistem pengolah musik ketika diantara sistem poengolah musik dan robot ada sebuah tembok yang menghalangi adalah 0,585 detik untuk penerimaan kondisi musik hidup dan 1,478 detik untuk kondisi musik mati.

\section{KESIMPULAN}

Berdasarkan penelitian hasil pengujian yang telah dilakukan terhadap robot humanoid dengan judul "Sistem sinkronisasi gerak tari antar robot humanoid" maka dapat ditarik kesimpulan seperti berikut. Untuk membaca frekuensi pada musik dapat digunakan modul audio analyzer V2.0. Robot yang dihasilkan oleh penelitian ini sudah dapat membedakan kondisi ketika musik sedang diputar atau dibisukan, dan antara robot 
1 dan robot 2 sudah dapat saling berkomunikasi. Komunikasi antar robot berfungsi supaya ketika salah satu robot ada yang terlambat mendapatkan data maka robot yang lainnya akan menunggu sampai robot yang terlambat menyelesaikan gerakannya sehingga robot 1 dan robot 2 kembali selaras. Pengiriman isyarat gerak robot menggunakan XBee S2C yang menggunakan metode zigbee yaitu dengan 1 master dan 2 router sudah dapat mengirimkan data dengan tingkat keberhasilan sebesar $100 \%$. Gerakan robot dengan musik pengiring sudah dapat berjalan dengan serasi.

\section{UCAPAN TERIMA KASIH}

Penulis mengucapkan terimakasih kepada editor, reviewer dan semua pihak yang telah mendukung penelitian ini atas segala masukan dalam proses penerbitan naskah. Semoga dengan hasil pencapaian dari penelitian ini dapat bermanfaat bagi penelitian-penelitian lainnya yang dilakukan pada masa mendatang.

\section{REFERENSI}

[1] Dikti, Tema dan Aturan Kontes Robot Seni Tari Indonesia (KRSTI) Tahun 2019. 2019.

[2] A. D. Deshmukh and U. B. Shinde, "A low cost environment monitoring system using raspberry pi and Arduino with Zigbee," Proc. Int. Conf. Inven. Comput. Technol. ICICT 2016, vol. 3, pp. 1-6, 2016. DOI: 10.1109/INVENTIVE.2016.7830096

[3] E. Ronen, C. O'Flynn, A. Shamir, and A. O. Weingarten, "IoT Goes Nuclear: Creating a ZigBee Chain Reaction," Proc. - IEEE Symp. Secur. Priv., pp. 195-212, 2017, DOI: 10.1109/SP.2017.14

[4] I. Maulana and N. S. Widodo, "Sistem Pengolah Musik Sebagai Kontrol Gerak Robot Humanoid," Bul. Ilm. Sarj. Tek. Elektro, vol. 1, no. 2, p. 46, 2019, DOI: 10.12928/biste.v1i2.915

[5] Aryanti, I. Mekongga, and H. Ramadhan, "Implementasi Sensor Suara Sebagai Pengendali Gerakan Robot Penari Humanoid dengan ATMEGA 8535," J. Penelit. Ilmu dan Teknol. Komput., vol. 8, no. 1, pp. 1-7, 2016. DOI: 10.5281/zenodo.3429001

[6] A. Zade, P. Rahangdale, and A. Giri, "X-bee Based Spy Robot with Night Vision Camera," Int. J. New Technol. Res., vol. 3, no. 2, pp. 63-66, 2017. Online

[7] T. Haryanto, A. Putra, D. Syauqy, and R. Maulana, "Sistem Pendeteksi Tempo Lagu Untuk Kontes Robot Seni Tari Indonesia (KRSTI) Berdasarkan Frekuensi Dengan Algoritma Beat This," J. Pengemb. Teknol. Inf. dan Ilmu Komput., vol. 3, no. 4, pp. 3986-3992, 2019. Online

[8] B. Fan, "Analysis on the Security Architecture of ZigBee Based on IEEE 802.15.4," 2017 IEEE 13th International Symposium on Autonomous Decentralized System (ISADS), Bangkok, 2017, pp. 241246. DOI: $10.1109 /$ ISADS.2017.23

[9] E. Sulistyo, "Sistem Komunikasi Robot Humanoid Dalam Aplikasi Robot Penari," semnastek, 2015. Online

[10] A. I. Bardani and N. S. Widodo, "Deteksi Zona pada KRSTI dengan Sensor Warna TCS3200," Buletin Ilmiah Sarjana Teknik Elektro, vol. 1, no. 2, p. 56, 2019. DOI: 10.12928/biste.v1i2.955

[11] R. Zahra, Thamrin, P. Jaya "Rancang Bangun Robot Humanoid Penari Gending Sriwijaya Menggunakan Modul Easyvr3,"VoteTEKNIKA, vol. 5, no. 2, 2017. Online

\section{BIOGRAFI PENULIS}

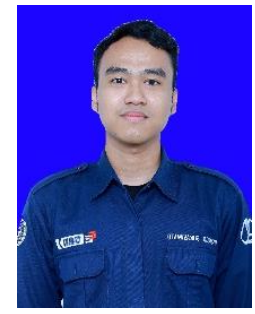

Ponco Sukaswanto

Ponco Sukaswanto adalah mahasiswa program studi teknik elektro universitas ahmad dahlan.

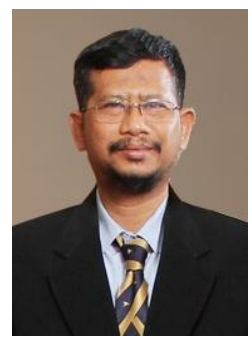

Abdul Fadlil

Abdul Fadlil adalah dosen program studi teknik elektro universitas ahmad dahlan. 